\title{
Prevalence of current smoking in Eastern province, Saudi Arabia
}

\author{
K.A. Al-Turki, N.A. Al-Baghli, ${ }^{7}$ A.J. Al-Ghamdi, ${ }^{7}$ A.G. El-Zubaier, ${ }^{2}$ R. Al-Ghamdi' and M.M Alameer ${ }^{3}$
}

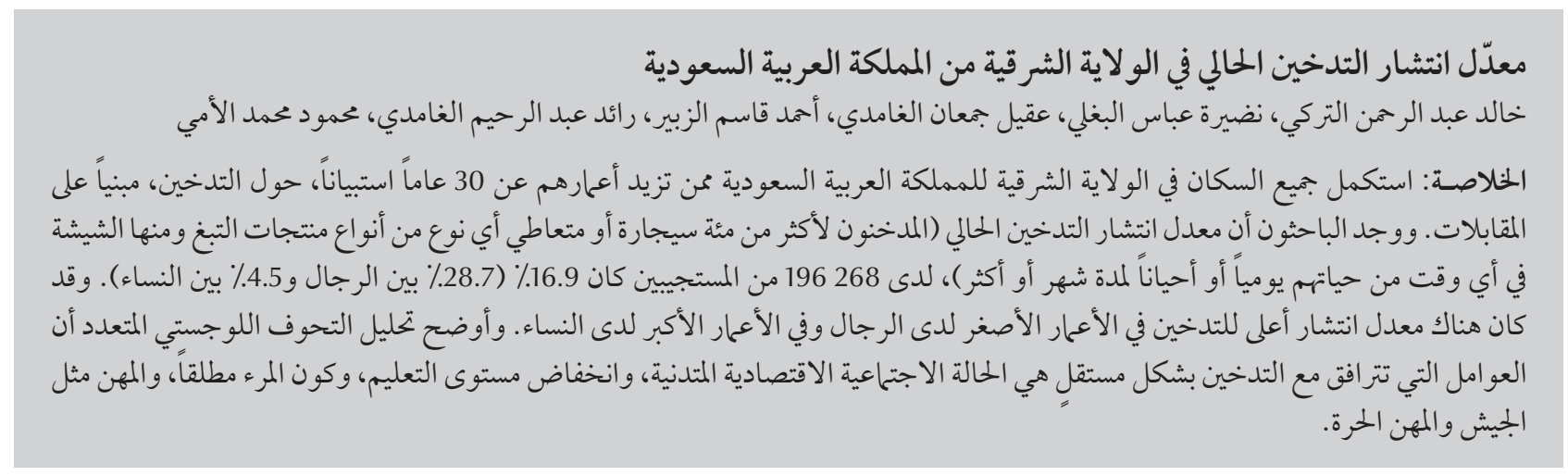

ABSTRACT All Saudi Arabian residents of the Eastern province of Saudi Arabia aged 30+ years completed a structured interview questionnaire about smoking. The prevalence of current smoking (smoked $>100$ cigarettes or any tobacco products including waterpipe in lifetime and still smoking daily or occasionally for 1 month or more) among 196268 respondents was 16.9\% (28.7\% among men and 4.5\% among women). There was a significantly higher prevalence of smoking at younger ages in men and older ages in women. Multiple logistic regression analysis showed that factors independently associated with smoking were lower socioeconomic status, lower education, being divorced and occupations such as the military and self-employed.

\section{Prévalence du tabagisme actif dans la province orientale d'Arabie saoudite}

RÉSUMÉ Tous les habitants de la province orientale d'Arabie saoudite âgés de 30 ans et plus ont rempli un questionnaire structuré sur le tabagisme. La prévalence du tabagisme actif (consommation de plus de 100 cigarettes ou de tout autre produit à base de tabac - y compris l'utilisation du narghilé - dans la vie, ou consommation journalière ou occasionnelle depuis un mois ou plus) chez 196268 répondants était de $16,9 \%(28,7 \%$ pour les hommes et 4,5\% pour les femmes). Cette prévalence s'est avérée significativement plus élevée chez les hommes jeunes et chez les femmes plus âgées. L'analyse de régression logistique multiple a montré que les facteurs indépendamment associés au tabagisme étaient un faible statut socioéconomique, un faible niveau d'éducation, le fait d'être divorcé ou l'exercice de certaines professions telles que militaire ou travailleur indépendant. 


\section{Introduction}

Smoking is a major preventable cause of morbidity and mortality. It is associated with a wide range of diseases: pulmonary, gastrointestinal and cardiovascular diseases and different kinds of cancers [1-3]. This creates a considerable economic burden for any nation. The World Health Organization has reported that more than 4 million annual deaths are attributed to tobacco consumption; this is projected to be10 million annually in 2030, most of the victims being from developing countries. While the prevalence of smoking in developed countries has been declining by $1 \%$ annually, the trend in developing countries is rising by $2 \%[4,5]$. Between 1990 and 1997, the Middle East and Asia were the only regions in the world where cigarette sales increased by $24 \%$.

In the Gulf Cooperation Council countries there are 30000 smokingrelated deaths per year, and $15 \%$ of total health care costs are spent on the treatment of smoking-related illness [6,7]. In Saudi Arabia estimates of the prevalence of tobacco consumption in different age groups vary widely, from $11.6 \%$ to $34.4 \%$ [8-13], possibly due to studies that focus on specific groups that are not representative of the whole population. In addition there are insufficient studies on smoking among women in Saudi Arabia. It has been noted that there are growing numbers of people, including women, who smoke waterpipes (shisha) and an increasing number of cafés serving shisha. Knowledge of the prevalence and factors associated with smoking is considered a baseline tool for evaluating the effectiveness of tobacco control programmes and for targeting antismoking initiatives on specific groups at risk.

We report here data on the prevalence of smoking in the Eastern province of Saudi Arabia and its association with sociodemographic and socioeconomic factors, with a focus on gender differences in smoking behaviour.

\section{Methods}

This study was part of a screening campaign conducted in the Eastern province of Saudi Arabia between 28 August 2004 and 18 February 2005. The methodology has been described previously [14]. A scientific committee established the detailed procedures for the campaign, including the standards for running the campaign, validation of instruments and health education materials to be used, staff training, financial supervision and data processing and entry. A media campaign was organized in each health sector (district) of the province using written and audiovisual materials, and posters on billboards in the streets and other public places.

\section{Sample}

The target population was all Saudi residents of the Eastern province of Saudi Arabia, aged 30 years and above, excluding pregnant women (650000 subjects). They were invited to participate in a screening campaign for the early detection of diabetes mellitus and hypertension by attending one of the $300+$ examination centres distributed in all primary health care centres, all government hospitals and most private hospitals and dispensaries in addition to mobile teams in public venues.

\section{Data collection}

A structured questionnaire for data collection was developed using information obtained from focus groups and validated by experts in the fields of diabetes and hypertension. Specially trained members of health teams interviewed the participants and completed the questionnaire.

The questionnaire comprised demographic information (age, sex, place of residence, marital status, occupation, education), medical history and lifestyle. Current smoking was defined by subjects' self-reports as having ever smoked $>100$ cigarettes and currently smoking, every day or occasionally, for 1 month or more before the campaign, any tobacco products including shisha. All others were considered nonsmokers.

Coordinators were assigned for each sector to supervise the examination centres, to ensure all forms were completed, to follow up defaulters and to liaise with coordinators in other health sectors and the main supervision committees. The forms were collected from each sector and were double-checked for completeness. Ineligible people were excluded and forms with incomplete data or unconfirmed results were sent back to the health sectors with a covering letter for corrections to be made.

The purpose of the campaign was explained to participants and they were assured of the confidentiality of the information collected. Health education materials were distributed to high-risk groups.

\section{Statistical analysis}

The data were analysed using SPSS, version 15 . Univariate analysis was performed to identify the association of sociodemographic factors with smoking prevalence. The significant variables were entered into a logistic regression analysis, where age was treated as a continuous variable and the rest as categorical variables. The results of the model are presented as odds ratio (OR) and 95\% confidence interval (CI). $P$-value $<0.05$ was the level of significance.

\section{Results}

The data of 196268 out of 197681 individuals who participated in the campaign were collected and included in the analysis; they comprised $30.2 \%$ of the total population of Saudi residents in the Eastern province. Men and women were $51 \%$ and $49 \%$ of the sample respectively.

The number of smokers was 33084 , giving a prevalence of current smoking of $16.9 \%$ (28.7\% among men and $4.5 \%$ among women, $P<0.001)$. Among men 
the highest prevalence was recorded in the youngest age group, 30-40 years $(32.5 \%)(P<0.001)$, whereas among women the highest prevalence was in the oldest age group, $\geq 70$ years $(8.5 \%)$ $(P<0.001)$ (Table 1). For occupation the highest rate of smoking was among military personnel, while professionals showed a significantly lower rate than other occupations $(P<0.001)$. Smoking declined as education increased. However, in the total sample younger people and those who were single were significantly more likely to smoke than married and older people.

Qateif and Safwa sectors had the highest prevalence of smoking ( $P$ $<0.001)$; the lowest prevalence was in
Oraera $(P<0.001)$ (Table 2). Among men, the highest prevalence was in Hafr Albaten (36.4\%) and the lowest in Oraera $(P<0.001)$. Among women the highest prevalence was in Safwa (23.1\%) and Qateif (17.8\%) (Table 2).

Due to the huge difference in the proportion of women who smoked in Qateif region than other regions, they

\begin{tabular}{|c|c|c|c|c|c|c|}
\hline \multirow[t]{2}{*}{ Variable } & \multicolumn{2}{|c|}{ Total $^{\mathrm{a}}$} & \multicolumn{2}{|c|}{ Men } & \multicolumn{2}{|c|}{ Women } \\
\hline & $\begin{array}{l}\text { No. of } \\
\text { respondents }\end{array}$ & $\%$ smoking & $\begin{array}{l}\text { No. of } \\
\text { respondents }\end{array}$ & \% smoking & $\begin{array}{l}\text { No. of } \\
\text { respondents }\end{array}$ & $\%$ smoking \\
\hline \multicolumn{7}{|l|}{ Age (years) } \\
\hline $30-40$ & 95385 & 17.9 & 48849 & 32.5 & 46534 & 2.5 \\
\hline $41-50$ & 56872 & 16.9 & 28348 & 28.4 & 28519 & 5.4 \\
\hline $51-60$ & 24201 & 16.7 & 12045 & 25.1 & 12154 & 8.4 \\
\hline $61-69$ & 11870 & 12.7 & 6395 & 17.5 & 5474 & 7.1 \\
\hline$\geq 70$ & 6369 & 10.6 & 3732 & 12.1 & 2637 & 8.5 \\
\hline \multicolumn{7}{|l|}{ Marital status } \\
\hline Single & 11636 & 20.9 & 5475 & 41.7 & 6161 & 2.4 \\
\hline Married & 172081 & 17.1 & 92992 & 28.0 & 79069 & 4.4 \\
\hline Widowed & 8296 & 8.5 & 416 & 18.5 & 7879 & 8.0 \\
\hline Divorced & 2662 & 8.2 & 260 & 40.4 & 2402 & 4.7 \\
\hline \multicolumn{7}{|l|}{ Occupation } \\
\hline Self-employed & 14286 & 30.7 & 13797 & 31.3 & 487 & 15. 6 \\
\hline Housewife & 71789 & 5.0 & $\mathrm{n} / \mathrm{a}$ & $\mathrm{n} / \mathrm{a}$ & 71784 & 5.0 \\
\hline Military & 21859 & 33.4 & 21857 & 33.4 & $\mathrm{n} / \mathrm{a}$ & $\mathrm{n} / \mathrm{a}$ \\
\hline Professional ${ }^{b}$ & 21577 & 14.2 & 12348 & 23.6 & 9229 & 1.6 \\
\hline Technical $^{c}$ & 8312 & 22.5 & 6089 & 29.6 & 2222 & 2.9 \\
\hline Non-technical ${ }^{\mathrm{d}}$ & 6376 & 27.7 & 5184 & 32.5 & 1192 & 6.8 \\
\hline Administrative & 34193 & 23.6 & 27916 & 28.3 & 6274 & 2.7 \\
\hline Unemployed & 12796 & 18.1 & 9948 & 22.2 & 2848 & 3.7 \\
\hline \multicolumn{7}{|l|}{ Education } \\
\hline Illiterate & 44875 & 10.5 & 11188 & 22.7 & 33685 & 6.5 \\
\hline Read \& write & 13790 & 13.1 & 5043 & 25.8 & 8745 & 5.9 \\
\hline Primary & 28332 & 20.8 & 14934 & 34.5 & 13396 & 5.6 \\
\hline Intermediate & 26811 & 23.4 & 17727 & 33.5 & 9081 & 3.7 \\
\hline Secondary & 41074 & 20.5 & 27128 & 29.9 & 13943 & 2.2 \\
\hline University & 35218 & 13.9 & 20160 & 23.2 & 15056 & 1.4 \\
\hline Higher degree & 1889 & 17.0 & 1419 & 21.6 & 470 & 3.0 \\
\hline \multicolumn{7}{|c|}{ Income (Saudi riyals/month) } \\
\hline$<2000$ & 35917 & 14.1 & 12904 & 29.0 & 23012 & 5.7 \\
\hline $2000-<5000$ & 50332 & 20.0 & 28141 & 32.1 & 22188 & 4.6 \\
\hline $5000-<7000$ & 35946 & 19.5 & 22466 & 29.5 & 13474 & 2.9 \\
\hline$\geq 7000$ & 47273 & 17.1 & 29843 & 25.6 & 17428 & 2.4 \\
\hline
\end{tabular}

${ }^{a}$ Totals vary due to missing data; ${ }^{b}$ All occupations requiring university bachelor or higher degree; ${ }^{c}$ Graduates from health, technical or commercial institutes; ${ }^{d}$ No academic studies.

All differences were statistically significant $P<0.001$.

$n / a=$ not applicable. 


\begin{tabular}{|c|c|c|c|c|c|c|}
\hline \multirow{2}{*}{ Health sector } & \multicolumn{2}{|c|}{ Total $^{\mathrm{a}}$} & \multicolumn{2}{|c|}{ Men } & \multicolumn{2}{|c|}{ Women } \\
\hline & $\begin{array}{l}\text { No. of } \\
\text { respondents }\end{array}$ & \% smoking & $\begin{array}{l}\text { No. of } \\
\text { respondents }\end{array}$ & \% smoking & $\begin{array}{l}\text { No. of } \\
\text { respondents }\end{array}$ & \% smoking \\
\hline Dammam & 30356 & 16.5 & 15547 & 30.4 & 14802 & 2.0 \\
\hline Khober & 30430 & 17.1 & 16588 & 30.6 & 13840 & 1.0 \\
\hline Qateif & 30673 & 22.8 & 14151 & 28.7 & 16522 & 17.8 \\
\hline Al-Hassa & 57337 & 13.6 & 29146 & 26.1 & 28183 & 0.8 \\
\hline Hafr Albaten & 11562 & 17.7 & 5393 & 36.4 & 6168 & 1.4 \\
\hline Ras Tanura & 5738 & 15.9 & 3130 & 28.6 & 2607 & 0.8 \\
\hline Bqaiq & 4753 & 12.6 & 2378 & 24.8 & 2372 & 0.4 \\
\hline Safwa & 4454 & 25.8 & 1893 & 29.6 & 2561 & 23.1 \\
\hline Jubail & 6649 & 18.6 & 3909 & 30.7 & 2740 & 1.4 \\
\hline Khafji & 4148 & 15.5 & 2090 & 30.0 & 2058 & 0.7 \\
\hline Oraera & 864 & 4.9 & 394 & 10.4 & 470 & 0.2 \\
\hline Nuaeria & 3841 & 18.0 & 2757 & 24.8 & 1084 & 0.6 \\
\hline Sarar & 2221 & 12.5 & 1029 & 25.3 & 1191 & 1.3 \\
\hline Qaria Olaya & 1897 & 14.3 & 1037 & 25.7 & 860 & 0.6 \\
\hline Rafeia & 1338 & 10.9 & 597 & 22.6 & 741 & 1.5 \\
\hline
\end{tabular}

${ }^{a}$ Totals vary due to missing data.

All differences were statistically significant $P<0.001$.

were studied separately to identify their sociodemographic characteristics. It was found that the highest rate of female smokers in Qateif was among the illiterate (35.5\%), widows (35.1\%), the self-employed (28.6\%), those with lower income $(27.7 \%)$ and in women older than 50 years $(36.0 \%)(P<0.001)$. In other sectors, the highest rate of female smokers was among the divorced $(1.6 \%)$ and the self-employed (12.3\%). Smoking was significantly higher among those with a higher degree of education $(2.5 \%)(P<0.001)$, and the rate was almost the same in all age groups.

\section{Regression analysis}

The regression analysis showed the factors independently associated with smoking were male sex, with the risk of being a smoker almost 13 times higher in men than women $(\mathrm{OR}=13.2 ; 95 \%$ CI: $12.9-15.3, P<0.001)$. The risk was significantly higher at younger ages in men and older ages in women ( Table 3). The smoking rate was higher among divorced people, although it was statistically significant in the case of women only. Among women, the self-employed were more than 5 times more likely to be smokers compared to other occupations. Higher education and income were negatively correlated with smoking in both sexes.

Regarding the geographical distribution of smoking in women, the odds ratios for being a smoker were 24.6 (95\% CI: 19.5-31.0) and 13.7 (95\% CI: 10.1-18.7) in Qateif and Safwa respectively $(P<0.001)$ compared with Hafr Albaten. The OR for women were greater than 2 in Dammam and Ras Tanura while in men the risk of smoking was significantly higher in Hafr Albaten $(\mathrm{OR}=1.12,95 \% \mathrm{CI}: 1.05-1.21,(\mathrm{P}$ $<0.001$ ) than other sectors.

\section{Discussion}

The reported prevalence of current smoking was $16.9 \%$ overall $(28.7 \%$ among men and $4.5 \%$ among women), which is higher than the prevalence of $12.9 \%$ (24.7\% among men and 1.4\% among women) reported previously for Saudi Arabia [15]. This difference could be attributed to a large extent to the lower rate of smoking reported among females in that study. Worldwide, the prevalence of smoking is much higher in men than in women [16]. Our results are consistent with this, although the difference between the sexes was especially large in our study (men were 13 times more likely to be smokers than women), which could be attributed to the social stigma attached to women being smokers in Saudi Arabia. However, it is also possible that our study underestimated the rate of female smoking, as there may have been under-reporting in spite of assurances to participants about the confidentiality of the data. The validity of self-reporting in determining the rate of smoking is often questioned [17]. A study in New England in the United States compared self-reported smoking behaviour by men and women and showed credibility in the use of selfreports of smoking in both sexes [18]. The situation may be different in our more socially conservative community, however, and this needs to be addressed in further research.

There was a wide range of smoking rates across the 15 geographical sectors 


\begin{tabular}{|c|c|c|c|c|c|c|}
\hline \multirow[t]{2}{*}{ Variable } & \multicolumn{3}{|c|}{ Men } & \multicolumn{3}{|c|}{ Women } \\
\hline & $\begin{array}{l}\text { Logistic regression } \\
\text { coefficient }\end{array}$ & OR & $95 \% \mathrm{CI}$ & $\begin{array}{l}\text { Logistic regression } \\
\text { coefficient }\end{array}$ & OR & $95 \% \mathrm{Cl}$ \\
\hline Age & -0.028 & 0.97 & $0.97-0.97$ & 0.018 & 1.02 & $1.01-1.02$ \\
\hline \multicolumn{7}{|l|}{ Marital status } \\
\hline Single & & $1^{\mathrm{a}}$ & & & $1^{a}$ & \\
\hline Married & -0.399 & 0.67 & $0.63-0.72$ & 0.481 & 1.62 & $1.29-2.03$ \\
\hline Widowed & -0.343 & 0.71 & $0.53-0.96$ & 0.432 & 1.54 & $1.19-1.99$ \\
\hline Divorced & 0.277 & 1.26 & 0.93-1.69 & 0.629 & 1.88 & $1.36-2.59$ \\
\hline \multicolumn{7}{|l|}{ Occupation } \\
\hline Self-employed & & $1^{\mathrm{a}}$ & & & $1^{\mathrm{a}}$ & \\
\hline Housewife & $\mathrm{n} / \mathrm{a}$ & $\mathrm{n} / \mathrm{a}$ & $\mathrm{n} / \mathrm{a}$ & -2.065 & 0.13 & $0.09-0.18$ \\
\hline Military & -0.130 & 0.88 & $0.83-0.93$ & $\mathrm{n} / \mathrm{a}$ & $\mathrm{n} / \mathrm{a}$ & $\mathrm{n} / \mathrm{a}$ \\
\hline Professional & -0.309 & 0.73 & $0.69-0.78$ & -1.427 & 0.24 & $0.16-0.36$ \\
\hline Technical & -0.115 & 0.89 & $0.83-0.96$ & -1.450 & 0.24 & $0.15-0.36$ \\
\hline Non-technical & -0.015 & 0.99 & $0.92-1.06$ & -1.901 & 0.15 & $0.10-0.23$ \\
\hline Administrative & -0.141 & 0.87 & $0.82-0.92$ & -0.942 & 0.39 & $0.27-0.57$ \\
\hline Unemployed & -0.130 & 0.88 & $0.82-0.94$ & -1.678 & 0.19 & $0.12-0.28$ \\
\hline \multicolumn{7}{|l|}{ Education } \\
\hline Illiterate & & $1^{\mathrm{a}}$ & & & $1^{a}$ & \\
\hline Read \& write & -0.038 & 0.96 & 0.88-1.05 & -0.159 & 0.85 & $0.74-0.98$ \\
\hline Primary & 0.142 & 1.15 & $1.08-1.23$ & -0.395 & -0.67 & $0.59-0.77$ \\
\hline Intermediate & 0.002 & 1.00 & 0.93-1.08 & -0.852 & 0.43 & $0.36-0.51$ \\
\hline Secondary & -0.206 & 0.81 & $0.76-0.88$ & -1.543 & 0.21 & $0.18-0.26$ \\
\hline University & -0.522 & 0.59 & $0.55-0.64$ & -2.246 & 0.11 & $0.08-0.14$ \\
\hline Higher degree & -0.584 & 0.56 & $0.48-0.65$ & -0.852 & 0.43 & $0.21-0.88$ \\
\hline \multicolumn{7}{|c|}{ Income (Saudi riyals/month) } \\
\hline$<2000$ & & $1^{\mathrm{a}}$ & & & $1^{\mathrm{a}}$ & \\
\hline $2000-<5000$ & 0.014 & 1.01 & 0.96-1.07 & -0.263 & 0.77 & $0.70-0.85$ \\
\hline $5000-<7000$ & -0.080 & 0.92 & $0.87-0.98$ & -0.509 & 0.60 & $0.52-0.69$ \\
\hline$\geq 7000$ & -0.031 & 0.97 & $0.91-1.03$ & 0.530 & 0.59 & $0.51-0.68$ \\
\hline
\end{tabular}

${ }^{a}$ Reference category.

$n / a=$ not applicable $; \mathrm{OR}=$ odds ratio; $\mathrm{Cl}=$ confidence interval.

studied, and this was especially marked for women. For example, although the overall prevalence of smoking in women was low, the rate in Qateif sector was more than 10 times higher than in other sectors. This has not been documented before, and the fact that the highest rate was among older, illiterate women could be explained by their habit of smoking qedow (a tobacco-smoking habit similar to the shisha), which is considered a community norm in older women and it is part of the local culture. It is hoped that this practice will decline over time, as the rate of smoking in the younger generation of women was similar to other regions in the Eastern province.

Generally, younger people have a greater tendency to be smokers than older people [10]. In our study the prevalence of smoking by age showed opposite trends in men and women, as we found the highest rate of smoking in men among the younger groups and the lowest rate among the older ages, while in women the lowest rate was in the younger group and it increased as they got older. However, it may be difficult to generalize from these data for women because most of the reported cases were among women from one region that has unique cultural habits. When Qateif region was excluded from the analysis, we found that smoking was more common among younger, better educated women, and this could be explained by the influence of the mass media in a previously closed community. A study conducted in Hong Kong has shown that one of the strongest risk factors for smoking by youths was their perception of cigarette advertisements as attractive [19]. Smoking initiation in young people and the factors contributing to it 
are well established [20] and constitute one of the main challenges for tobacco control programmes [21].

Similar to other studies [22,23], our findings revealed that smoking tended to be more prevalent among military personnel and blue-collar workers and those with lower education and income, and this can be explained by stressful working environments [24] and peer influences in some occupations $[19,20]$. These are factors which needed to be addressed in order to focus on an effective strategy for smoking cessation and prevention in these groups.
It is important to recognize the limitations of this study. Our questionnaire did not address ex-smokers, the type and intensity of smoking or a history of passive smoking; it also depended on self-reported smoking behaviour and it did not involve school-age subjects. On other hand it had its strengths; the response rate among the subjects participating in the campaign was high (99.3\%), presumably due to the efforts of quality control supervision, and almost one-third of the population was involved in this study. In addition, the close comparability of the proportion of our participants by age and sex compared with the latest census in the Eastern province of Saudi Arabia [25] makes this study a representative estimate of the prevalence of smoking in Eastern province.

\section{Conclusions}

The results of this large communitybased study showed a high prevalence of smoking in Saudi Arabia and that age, sex, education and occupation were important demographic factors predicting the likelihood of tobacco consumption.

\section{References}

1. Liu BQ et al. Emerging tobacco hazards in China: retrospective proportional mortality study of one million deaths. British medical journal, 1998, 317:1411-22.

2. Doll $\mathrm{R}$ et al. Mortality in relation to smoking: 40 years' observation on male British doctors. British medical journal, 1994, 309:901-11.

3. Gupta1 PC et al. Tobacco associated mortality in Mumbai (Bombay) India. Results of the Bombay Cohort Study. International journal of epidemiology, 2005, 34(6):1395-402.

4. Smoking and health in the Americas. Atlanta, Georgia, Centers for Disease Control, US Department of Health and Human Services, 1992 (DHHS publication No, CDC 928419).

5. Achievements in public health, 1990-1999. Tobacco useUnited States, 1990-1999. Morbidity and mortality weekly reports, 1999, 48(43):986-93.

6. The economics of tobacco in the Eastern Mediterranean Region. Cairo, World Health Organization Regional Office for the Eastern Mediterranean, 2004.

7. Al-Bedah AM. The economics of tobacco in GCC countries. Riyadh, Saudi Arabia, Technical Office of the Arab Health Minister's Council for GCC States, 2001.

8. Jarallah JS et al. Predictors of smoking among male junior secondary school students in Riyadh, Saudi Arabia. Tobacco control, 1996, 5:26-9.

9. Al-Damegh SA et al. Cigarette smoking behavior among male secondary school students in the Central region of Saudi Arabia. Saudi medical journal, 2004, 25(2):215-9.

10. Siddiqui S, Ogbeide DO, Al Khalifa I. Smoking in a Saudi community: prevalence, influencing factors, and risk perception. Family medicine, 2001, 33(5):367-70.

11. Al-Faris EA. Smoking habits of secondary school boys in rural Riyadh. Public health, 1995, 109(1):47-55.

12. Al-Yousaf MA, Karim A. Prevalence of smoking among high school students. Saudi medical journal, 2001, 22(10):872-4.

13. Siddiqui S, Ogbeide DO, Profile of smoking amongst health staff in a primary care unit at a general hospital in Riyadh, Saudi Arabia. Saudi medical journal, 2001, 22(12):1101-4.

14. Al-Ghamdi A et al. A community-based screening campaign for the detection of diabetes mellitus and hypertension in the eastern province, Saudi Arabia: methods and participation rate. Journal of family \& community medicine, 2007, 14(3):91-7.

15. STEPwise surveillance program for KSA: preliminary report. Riyadh, Saudi Arabia, Ministry of Health, General Directorate of Non-Communicable Disease, 2005.

16. Grunberg NE, Winders SE, Wewers ME. Gender differences in tobacco use. Health psychology, 1991, 10:143-53.

17. Patrick DL et al. validity of self-reported smoking: a review and meta-analysis. American journal of public health, 1994, 84(7):1086-93.

18. Assaf AR et al. Are there gender differences in self-reported smoking practices? Correlation with thiocyanate and cotinine levels in smokers and nonsmokers from the Pawtucket Heart Health Program. Journal of women's health, 2002, 11(10):899906.

19. Lam TH et al. Tobacco advertisement: one of the strongest risk factors for smoking in Hong Kong students. American journal of preventive medicine, 1998, 14(3):217-23.

20. Gritz ER et al. Predictors of susceptibility to smoking and ever smoking: a longitudinal study in a triethnic sample of adolescents. Nicotine and tobacco research, 2003, 5(4):493-506.

21. Cigarette smoking among adults-United States, 1998. Morbidity and mortality weekly reports, 2000, 49:881-4.

22. Patterson JM et al. Associations of smoking prevalence with individual and area level social cohesion. Journal of epidemiology and community health, 2004, 58:692-7.

23. Shohaimi $\mathrm{S}$ et al. Residential area deprivation predicts smoking habit independently of individual educational level and occupational social class. A cross sectional study in the Norfolk cohort of the European Investigation into Cancer (EPICNorfolk). Journal of epidemiology and community health, 2003, 57(4):270-6.

24. Patterson JM et al. Associations of smoking prevalence with individual and area level social cohesion. Journal of epidemiology and community health, 2004, 58:692-7.

25. Population and housing characteristics in the Kingdom of Saudi Arabia demographic survey 1428 H(2007). Riyadh, Saudi Arabia, Ministry of Economy and Planning, Central Department of Statistics and Information Population and Vital Statistics, 2007. 